\title{
ATAT1 wt Allele
}

National Cancer Institute

\section{Source}

National Cancer Institute. ATAT1 wt Allele. NCI Thesaurus. Code C94842.

Human ATAT 1 wild-type allele is located in the vicinity of $6 \mathrm{p} 21.33$ and is approximately 20

$\mathrm{kb}$ in length. This allele, which encodes alpha-tubulin $\mathrm{N}$-acetyltransferase protein, may

play a role in neuronal development. 